Article

\title{
A Method for Development of Ecomuseums in Taiwan
}

\section{Zhen-Hui Liu ${ }^{1}$ and Yung-Jaan Lee ${ }^{2, *}$}

1 Department of Geography, National Taiwan University, No. 1, Section 4, Roosevelt Road, Da'an District, Taipei 10617, Taiwan; E-Mail: dennis01liu@gmail.com

2 Chung-Hua Institution for Economic Research, No. 75, Chang-Hsing Street, Da'an District, Taipei 10672, Taiwan

* Author to whom correspondence should be addressed; E-Mail: yungjaanlee@gmail.com. Academic Editor: Gianna Moscardo

Received: 31 July 2015 / Accepted: 22 September 2015 / Published: 25 September 2015

\begin{abstract}
One component of the new museology is the ecomuseum, which is intended to preserve cultural/natural heritage and the local landscape in situ, and involves community participation and needs associated with community development. Since the ecomuseum concept originated in Western Europe, ecomuseums must be adapted or localized to various socio-economic environments. In the 2000s, two mining ecomuseums were established in New Taipei City - the Gold Museum and the Houtong Coal Mine Ecological Park. In the early 2010s, two more ecomuseums were established - the Daxi Wood Art Ecomuseum and the Togo Art Museum. More than the mining ecomuseums, the Daxi Wood Art Ecomuseum emphasized community participation and the vision of the Togo Art Museum was led by the community. Based on an analysis of the Houtong Coal Mine Ecological Park, the Daxi Wood Art Ecomuseum and the Togo Art Museum, this study elucidates the various mechanisms of the development of ecomuseums in Taiwan. Ecomuseums should be interconnected with the community and the environment. The three major functions of ecomuseums (community participation, local development, and in-situ preservation) can promote sustainable development. This study uses the "creativity triangle" concept with a three-year cycle of development as an analytical tool. The concept was modified to include three stages of development, which are "estimation", "preparation", and "operation"; six steps and 11 tasks are proposed. Despite the unique circumstances of each ecomuseum, this study provides an overview of the development processes and provides a basis for making recommendations for establishing other ecomuseums in Taiwan.
\end{abstract}


Keywords: ecomuseum; community participation; local development; in-situ preservation

\section{Introduction}

In the new museology [1] (pp. 105-106), an ecomuseum is a museum for, by, and about people in their own environment and in a setting that promotes the transmission and protection of heritage and is developed through a community-based method [2,3]. The term "ecomuseum" combines the concepts of "ecology" and "museum", created by Hugues de Varine, who was the Director of the Secretariat for the International Council of Museums (ICOM) from 1965 to 1974. The concept was developed in 1971 for the purposes of the French Minister for the Environment, Robert Poujard. Ecomuseums combine the concepts of ecology, communities, and open-air museums in Scandinavia and in France; they are governed by public policy regarding regional natural parks. The concept is commonly connected with the re-usage of industrial heritage in the UK and neighborhood museums in the USA. The international new museology movement is commonly regarded as a counterpoint to conventional museums.

George Henri Rivière, the Director of the ICOM Secretariat from 1948 to 1965, before the tenure of Hugues de Varine, was one of the most important promoters of the ecomuseum movement. He offered the third definition of the ecomuseum in January 1980. In his opinion, "an ecomuseum is an instrument conceived, fashioned and operated jointly by a public authority and a local population"; "the public authority's involvement is through the experts, facilities and resources it provides; the local population's involvement depends on its aspirations, knowledge and individual approach" [4] (pp. 182-183). Owing to the former position of George Henri Rivière, this definition is widely known and has had a great influence on the development of ecomuseums. According to Darko Babić, however, ecomuseums "change and adapt depending on time, space, and most of all, population, the community in which they operate and its developmental needs, so the definitions are also always evolutive" [5] (p. 245).

To identify the fundamental principles of ecomuseums in France, Jean-Philippe LECAT, minister of Ministère de la Culture et de la Communication from 1978 to 1981, issued the "Ecomuseum Charter", on 4 March 1981. Consistent with the concept that was developed by George Henri Rivière, Article I briefly defines an ecomuseum as "a cultural institution that provides, with the participation of the population, the functions of research into, and the conservation and presentation of natural and cultural property and representative environment and lifestyles that follow one another" [6].

Ecomuseums have been established in many other European countries [7]. On 5-8 May 2004, a workshop entitled, "Long Networks, Ecomuseums and Europe" was held in Trento, Italy. The participants agreed to establish the European Network of Ecomuseums. This declaration clearly defined the ecomuseum as "a dynamic way in which communities preserve, interpret, and manage their heritage for a sustainable development" and "an ecomuseum is based on a community agreement" [8].

One Asian country that is highly committed to the ecomuseum movement is Japan. On 26 March 1995, ecomuseum promoters and participants in Japan established the Japan Ecomuseological Society (JECOMS). The JECOMS published the "2009 Ecomuseum Charter" on 24 May 2009. This charter was based on the evolutionary definition of the ecomuseum that was provided by George Henri Rivière and outlined the definition, goals, activities and mechanism of ecomuseums in Japan. As in the French model, 
the Japanese ecomuseum consisted of a school, a laboratory and a conservation organization. However, JECOMS defined the ecomuseum as "a mechanism for exploring the relationship among human activities, the participation of residents and the environment for the purpose of sustainably contributing to the community-endogenous development" [9].

The Chinese and Norwegian governments cooperatively developed an ecomuseum project in 1997 . The first ecomuseum in China (Soga Ecomuseum) was established in 1998 [10]. To regulate ecomuseums, China established the "Liuzhi Principles" in 2000, which were widely adopted by international museum experts in 2005. These principles begin by asserting that the inhabitants of villages are the true "owners" of their culture and they have the right to interpret and validate it themselves. According to the Liuzhi Principles, public participation is critical to ecomuseums, and culture is a common and democratic asset that must be democratically managed [11].

Ecomuseums are a popular topic of research in various academic fields. Chang [3] developed an interdisciplinary landscape approach, focusing on the connections between the ecomuseum and the landscape to guide ecomuseum management and landscape administrators. Following the first and the second museology revolutions, Cândido proposed the need for a third revolution, based on the experience in Brazil that involved radical engagement with social change [12]. Terzić et al. [13] applied principles and practices associated with ecomuseums, cultural routes and cultural district ideals to explore the synergies among landscape, heritage and festivals (living culture), with a view to safeguarding and conserving heritage resources and promoting tourism at the "Ibar Valley" ecomuseum in Serbia. An ecomuseum turns an entire area into a museum, and so differs from a conventional museum, which attracts audiences to collections that are exhibited in a limited space. Kim and Lee [14] proposed the use of an ecomuseum to contribute to the activation of a sustainable local economy in Cheorwon, Korea, based on military cultural relics and historical cultural assets. González and Fernández discussed a cultural heritage management project in the impoverished and depopulated territory in Santo Adriano, Spain. The goal of the project was to establish a common framework for local action that involved various social actors in an ecomuseum, including public institutions, the church, neighbours and other private owners of heritage sites, the local community, private companies and visitors [15] (pp. 246, 249). Sanya addressed the question of whether traditional building heritage realistically contributed to an alternative development model and suggested "a dynamic ecomuseum model conceptual frame that takes a leaf from Critical Regionalism as a comprehensive theory allowing both reaffirmation and transcendence of the local" [16] (pp. 2,21). With respect to the ecomuseum experience in Japan, Ohara claimed "good relationship between traditional museums and participative activity of local people is an important element for composing an ecomuseum, but many ecomuseums in Japan had poor relations with established museums and museology" [17] (p. 257). In contrast, Nitzky investigated nine contemporary top-down Chinese government-led ecomuseum projects and defined an ecomuseum as " $a$ strategy to preserve cultural heritage and stimulate economic development in impoverished ethnic minority regions" [18] (p. 367). Cerleux et al. [19] modeled an organization of ecomuseums for general implementation as "a new instrument in territorial management action". The model comprised two components - resources and territorial players, who act in situ or ex situ.

According to the above definitions and discussions of various issues around ecomuseums, the ecomuseum concept can make an important contribution to the Western/Eastern world, developed/ developing/underdeveloped countries, urban/rural regions and tangible/intangible heritage, and can help 
to preserve both cultural and natural resources. Most relevant studies emphasize public participation, and especially the involvement of the community or local population. Unlike traditional museums, which focus on the contents of the museum, ecomuseums are concerned with preserving cultural/natural heritage and the local landscape in situ and commonly depend on community participation and are aligned with the developmental needs of the community. Therefore, an ecomuseum can be an institution, instrument, or mechanism for achieving these purposes. Studies of Japanese ecomuseums have demonstrated that community participation is more important than tangibility, and some ecomuseums in Japan have used a decentralized structural model to replace the widely spread "core and satellite" system [20]. The most important task is to develop a sustainable mechanism for implementing the exciting and revolutionary ideas that challenge the limitations and problems of conventional museums.

\section{Localization of Ecomuseums in Taiwan}

Borrelli and Davis noted that the total number of ecomuseums globally exceeds 400. Of these, approximately 350 are located in Europe [21]. In the opinion of Giménez-Cassina, "the term 'ecomuseum' became such a powerful marketing tool, that the use of the label might seem convenient" but "it does not always stick to its original intentions, the foundations that (Hugues) de Varine and (George Henri) Rivière proposed in the 1970s" [22] (p. 33).

Chang [3] argued that, whereas ecomuseums are based on democracy and community-orientated principles, many societies are non-democratic or hierarchical. Therefore, some adaptation is needed, and the adaptation or the localization of ecomuseum-related concepts or theories that were developed in different socio-economic environments is an important issue that warrants further study.

No formal definition or official policy has been established concerning ecomuseums in Taiwan. However, the ecomuseum concept is well established both academically and practically. "Museology Quarterly", published by National Museum of Natural Science, is one of the most important journals for museology in Taiwan. In journal No. 3 of Vol. 6, published in July 1992, there was a Chinese translation of an article concerning the development of the ecomuseum concept in Sweden [23] (pp. 206-210). In January 1996, journal No. 1 of Vol. 10 was published as a special issue that was entitled, "Ecomuseum", which included ten theses or articles. Six of the articles were translations [4,24-28] and the others were written by native professionals. In 2004, a book entitled, "Ecomuseums: the Rise of a Cultural Movement" by Yu-Teng Chang, was published [29]. The ecomuseum concept has gradually become familiar not only in the academic sphere but also to the public.

Apart from the promotion by museum communities, the Council for Cultural Affairs (CCA) proposed the concept of "community empowerment" to reduce alienation in urbanized society in 1994. Supported by relevant policies, some residents have sought to rediscover their communities, preserve or strengthen existing identities, and even create new identities through community empowerment and community activities. Numerous local authorities have also attempted to characterize their locales and have sponsored cultural and artistic festivals or established facilities for the exhibition and performance of particular local interests. At the start of the 21 st century, CCA promoted the re-use of redundant spaces for cultural purposes and connected railway warehouses into a network of artist villages. CCA, which was upgraded to the Ministry of Culture (MOC) on 20 May 2012, initiated a long-term (2002-2015) project to support municipalities and the private sector in instituting, managing and improving "local 
cultural museums". The purpose was to create "cultural living circles" [30]. With the adoption of the ecomuseum concept and the promotion of the relevant policies, more than 50 ecomuseums were proposed of which 18 were implemented (Figure 1).

\begin{tabular}{|l|}
\hline 1.Beitou Hot Spring \\
Museum \\
2.Meinong Hakka Cultural \\
Museum \\
3.Shihsanhang Museum \\
of Archaeology \\
4.Taoyuan Military \\
Community Story House \\
5.Gold Museum \\
6.Jingtong Mining \\
Industry Museum \\
7.Wulai Atayal Museum \\
8.Tamsui Historical \\
Museum \\
9.Bopiliao Historic Street \\
10.Kaohsiung Museum of \\
Military Dependents \\
Village \\
11.Formosan Golden \\
Bat's Home \\
12.Penghu Living \\
Museum \\
13.Houtong Coal Mine \\
Ecological Park \\
14.Lanyang Museum \\
15.Liudui Hakka Cultural \\
Park \\
16.Sun Moon Lake \\
Ecomuseum \\
17.Togo Art Museum \\
18.Daxi Wood Art \\
Ecomuseum \\
\hline
\end{tabular}

Studying cases in this article
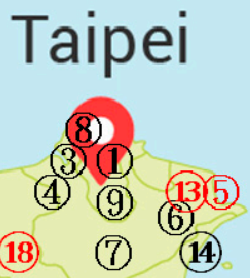

(12)

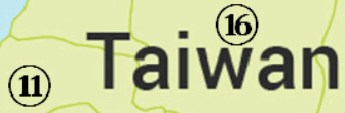

(17)

(2)

(10) (15)

Figure 1. Map of ecomuseum-like facilities in Taiwan.

On account of the particular socio-economic environment of Taiwan, various community organizations lack the man-power and financial resources to run ecomuseums. Accordingly, only four ecomuseum-like facilities, including the Taoyuan Military Community Story House, the Formosan Golden Bat's Home, the Sun Moon Lake Ecomuseum, and the Togo Art Museum, are run by local communities. Most of ecomuseum-like facilities must become more integrated with the surrounding environment and encourage multi-stakeholder participation to become the real ecomuseums of the future. A review of the establishment of these ecomuseum-like facilities suggests that the ecomuseum movement in Taiwan can be divided into three periods - the trial-and-error period in the 1990s, the implementation period in the 2000s, and, finally, the development stage in the 2010s. The Gold Museum, the Houtong Coal Mine Ecological Park, the Togo Art Museum and the Daxi Wood Art Ecomuseum are representative of the latter two periods. Of the " 21 Ecomuseum Principles", Davis noted "it is rare 
that all the principles in the above list are used; their adoption in very much dependent upon local conditions, and selective use has led to different kinds of ecomuseum being created [7] (p. 94)". The Gold Museum, the Houtong Coal Mine Ecological Park, the Daxi Wood Art Ecomuseum and the Togo Art Museum apply 12, 15, 18 and 19 of these principles, respectively.

In New Taipei City, the ecomuseum concept was applied in establishing two mining ecomuseums in the Ruifang District during the 2000s. The Ruifang District was once the most important mining region in Taiwan and is famous for gold mining and coal mining. On 4 November 2004, the Gold Museum formally opened. By preserving and exhibiting some of the gold mining and related facilities in the Jinguashi region in situ, the Gold Museum soon became a renowned tourist destination. However, because of its weak links with the local communities, and especially the surrounding mining villages, the Gold Museum resembled an open-air museum rather than an ecomuseum; this issue has been gradually addressed by the active participation of the local communities and changes in the vision and strategy of the museum.

The Houtong Coal Mine Ecological Park was located in the coal mining region that neighbors the region of the Gold Museum and was the most productive coal mining region in Taiwan after the Second World War. In 1990, the coal mining industry ceased because of a decrease in mining resources and policies to promote mining safety. Ninety years later, the mining facilities that remain in this area include the mines, the bridges and railroad system for transporting coal ores, factories and offices of the mining industry, related community activity centers, the welfare shop, the restaurant and dormitories for mining workers and the mining villages themselves. This industrial heritage makes the site suitable for an ecomuseum. However, in the late 1990s, under pressure from mining communities, the local authority decided to build a coal mine museum, which failed in the early 2000s, and then it was re-designated as an ecomuseum that used tangible and intangible cultural resources and the built environment to promote an integrated redevelopment policy.

The master plan of the Houtong Coal Mine Ecological Park focused not only on mining heritage space and antiquities inside the properties but also on integration of the natural environment, the lifestyle of the local population, and the social process. The framework proposed one core zone, two satellite regions, six community living circles, one fieldwork school camp, and various discovery trails [31] (pp. 68-74). The decaying mining landscape and environment has been rehabilitated for preservation and further development, and some mining industry artifacts have been restored or transformed for exhibition or tourism. Examples include the arch bridge across Jilong River, the warehouse and the office close to the coal dressing plant, the room for drying sand and some of the public baths for workers and miners. The Houtong Coal Mine Ecological Park finally opened on 24 July 2010. Most exhibition and educational facilities are managed by a university and a local community organization. The park is now a popular tourist destination in Taiwan, especially on weekends or holidays, and the total number of visitors in 2014 exceeded 800,000.

The Houtong Coal Mine Ecological Park has the potential to contribute to environmental education. Tourists can not only visit the exhibition and artifacts of the mining industry but also experience and imagine the complete operational process of the mining industry. The boundary of the Houtong Coal Mine Ecological Park takes in the mining villages of Guangfu Village, Houtong Village and Gongqiao Village, enabling visitors to engage with the retired workers and their families, who share their memories and provide a local perspective on mining history and related stories and technologies. However, 
owing to this boundary, some residents expected the ecomuseum project to catalyze regional development, while many were worried about the impact of large numbers of tourists on their quality of life by making noise, generating garbage, and causing traffic accidents. Balancing these two needs has been an important but difficult issue for the Houtong Coal Mine Ecological Park.

In the early 2010s, two more ecomuseums were established - the Daxi Wood Art Ecomuseum and the Togo Art Museum. The Daxi Wood Art Ecomuseum is located in the Daxi District of Taoyuan City, and was one of the first experimental sites, under the community empowerment policy, initiated in 1996. The Daxi Old Street was known as a historic region with its Baroque-style facets and woodcraft, especially the Buddhist table and related furniture. The Daxi Old Street is a popular tourist attraction in Taiwan. Since 2012, in consultation with the local community and in alignment with Taiwan's cultural policy, the local authority has begun to promote the construction of an ecomuseum with local woodcraft as a theme. During the preparation period, the local authority not only preserved historic buildings for re-using as museum facilities but also involved the local residents in the establishment of the ecomuseum and its ongoing management. This ecomuseum, which officially began operations on 1 March 2015, was developed by an unprecedented public-private partnership that is highly consistent with the purpose of ecomuseums.

Unlike the other three ecomuseum-like facilities, the Togo Art Museum, located in the Houbi District of Tainan City, was constructed by the Togo Rural Culture Community Development Organization, which was founded in 2002 by local people to improve the community environment. From 2002 to 2012, artists, academic groups, and volunteers were invited to participate in the construction of artistic spaces and creation of art. To involve in the community more deeply and continuously, six students who graduated from Tainan National University of the Arts decided to live in Togo Village and start new businesses that were related to community development. After a decade of continuous gestation and accumulation, the concept of the Togo Art Museum was eventually realized, helping this rural village achieve sustainable development stage by advocating "the rural village is an art museum". On 16 December 2012, the museum officially began operations. The Togo Art Museum provided an opportunity to implement an ecomuseum from the bottom up to meet the needs of local residents and obtain a balance between the quality of rural life and the need for development.

\section{Research Method}

Action research is a strategic method for generating knowledge; it integrates a wide range of methods to create new understandings that support the solving of practical problems and the democratic control of solutions by participants [32]. As a researcher in this field, one of the authors of this study, Liu, carried out action research at the Houtong Coal Mine Ecological Park from 2007 to 2013. Throughout this period, participative observations were made and questionnaire investigations and fieldwork interviews were conducted not only to record events in the field but also to elucidate why and how local people affect ecomuseum development.

From 2007 to 2010, Liu was a training course lecturer and adviser for many projects and advised on several issues associated with cultural and natural heritage preservation and community participation in the Houtong Coal Mine Ecological Park. Through involvement in community activities and discussion of local issues, proposed plans and the execution of the local projects, Liu collected first-hand information 
and established friendships and partnerships with many community members. As well as providing training courses and writing a report, Liu gathered 96 responses to questionnaires about local residents' opinions of community participation in the ecomuseum project, based on the 21 Ecomuseum Principles, and especially those concerning community-related issues [7] (pp. 92-93). The opinions of 39 visitors concerning community activities and 19 records of the activities and meetings of the community were obtained with a view to collecting the ideas of external visitors and local residents concerning the development of the ecomuseum project during this period.

Following the opening of the Houtong Coal Mine Ecological Park, in 2011-2013, tourism and local development became critical issues. In that period, Liu formally interviewed 11 stakeholders and informally interviewed 14 stakeholders to exchange and communicate opinions and ideas about ecomuseum-related issues with the goal of proposing a mechanism for sustainable development within the Houtong Coal Mine Ecological Park - not only to maintain the operation of the ecomuseum but also to balance preservation with developmental needs.

To extend the findings beyond those of a single case study, Liu examined the initiation and establishment of the Gold Museum, the Daxi Wood Art Ecomuseum and the Togo Art Museum by reviewing relevant literature, undertaking field investigations and interviewing stakeholders. Based on the experience of long-term action research at the Houtong Coal Mine Ecological Park, the results of this study concerning the Houtong Coal Mine Ecological Park are compared with the obtained information about the other three ecomuseums to propose an ecomuseum development mechanism that is consistent with the local context.

\section{Action Research Findings}

\subsection{Community Participation in Houtong Coal Mine Ecological Park}

The master plan of the Houtong Coal Mine Ecological Park takes into account critical issues related to ecomuseums. However, this ecomuseum project was led by the tourism department of the local authority, which was at first primarily concerned with the infrastructure and museum facilities, such as the small galleries and tourism centers. During this period, the authority seldom considered the opinions or needs of local residents. In 2007, the ecomuseum project became increasingly visible and some of the abandoned mining facilities, such as the warehouse and the mining office in front of the station, were restored, encouraging local people to care about it. Opposition coalesced around a community program called "Action for a Beautiful Hometown". In 2008, the most active community organization in the Houtong region, "Houtong Community Development Association", advocated that the ecomuseum should be consistent with the vision of the local community and initiated a community project called "Planning of Houtong Ecomuseum (Community Version)". Local communities were particularly concerned about the participatory process and expected the government to consider the opinions of local people and follow the international principle of authenticity and integrity during the preservation and restoration. With respect to management issues, the government was expected to use local manpower and to control the number of tourists to prevent degradation of the living environment or the quality of life. Participating residents continued to examine cultural and natural resources in this region, based on work done in previous years, under five categories - coal mining, dwelling, life, leisure and landscape. 
Important items were identified on a community map called "Houtong Roaming", and three discovery trails were designed through a participatory process.

Motivated by the community programs in 2007-2008, in 2009-2010, local residents began to communicate with local authorities in community activities and through meetings. The tourism department began to work with local residents in 2010. To encourage residents to participate in the opening ceremony and to increase the identity of this ecomuseum, a series of empowerment programs were held for local residents from June to July. The participants in these courses not only developed the interpretative trails in detail, but also produced a special local recipe called "Coal Time Rice Ball", and developed tutorials for the do-it-yourself (DIY) production of plaster-cast leaves for recording local natural resources. These residents then planned and tested a nature tour and two community tours for the opening day and the next day. The relevant results of the questionnaire were positive: of the community participants, more than $70 \%$ wanted to participate in future community activities; $94 \%$ agreed to found a new organization to increase cooperation among the three villages in the Houtong region and to establish a working platform for improving public-private partnership; and for external visitors, they gave an average score of 8.13 out of 10 for the three local tours. The feedback was used for further optimization and redevelopment of this post-industrial region for the benefit of local residents, who established a new organization called "Association for the Sustainable Development in the Place of Houtong", at the end of 2010. Beyond focusing on the region's coal mining heritage, since 2011, the organization has conducted guided tours in the flowering season to observe a special plant called "Bretschneidera sinensis Hemsl." that survived the ice age.

Additionally, one of the community members, who founded the Black Gold Cultural Studio, wanted to allow visitors to experience the community environment, and especially the atmosphere inside the coal mine, so she appealed to the local community to hold a night parade on 26 December 2009, during which some streetlamps were turned off, and participants wore DIY headlamps and were guided by local residents. This unique community festival was continued from 2010 to 2012. In 2010, the host invited a musical group from the neighboring Jinguashi region to demonstrate the creativity of the mining population and inspire Houtong residents to follow the Jinguashi approach. Subsequently, in 2011 and 2012, a performance by the community troupe was added to tell the stories of specific local residents and share the collective memories of the community.

Following the active involvement of the local residents, visitors became involved. For example, a cat lover found several street cats in the Houtong region in 2008. These cats mostly lived in the small area behind the railroad station called "Chetouding Village", which is now widely known as the "Cat Village". She photographed these cats and posted her pictures on the website. A volunteer group of cat lovers gradually formed and attracted many members. The group visited the Houtong region and played with and photographed the cats. In 2009, a successful cat photography exhibition was held. The exposure of this location caused many people to clean and beautify the environment. Visitors brought food and helped to neuter the cats to control their numbers in the Houtong region. These people and their activities became known as the "Houtong Cat Village Movement". To provide a sustainable cat-friendly environment, the volunteers established the "Taiwan 319 Cat Lovers' Association" and held the first "Houtong Cat Lamp Blessing Festival" in 2012. The community was decorated with red lamps, on which were hand-drawn cats, and with art installations. People were encouraged to experience this 
special regional event. Following the involvement of the local authority and other community groups, the cats became another important attraction in the Houtong region.

Various community activities were carried out in the Houtong Coal Mine Ecological Park in the year 2003-2013. Under the authority of the local tourism department, a series of public meetings and empowerment courses were held in 2010, and further assistance and support have been provided for local activities since 2012. The cooperation among community organizations and the local authority, especially the tourism department, gradually improved. However, the cooperation was mostly ad hoc. According to the 21 Ecomuseum Principles, an ecomuseum should "be steered by the local community", "allow for public participation from all the stakeholders and interest groups in all the decision-making processes and activities in a democratic manner", "stimulate joint ownership and management with input from local communities, academic advisors, local businesses, local authorities and government structures", and "depend on substantial active voluntary efforts by local stakeholders" [7] (pp. 92-93). However, under the socio-economic environment in Taiwan, the principle of "being steered by the local community" cannot put into effect so easily. The Houtong Coal Mine Ecological Park was initiated by the local authority and covered three local villages, whose residents should be included in decisions regarding the ecomuseum and not just "helped" or "served". As the "Cat Village" movement developed, the local authority founded a new information center to improve the public's knowledge of the health of cats and in 2014 authorized the Association for the Sustainable Development in the Place of Houtong to manage, representing a new milestone in cooperation between the ecomuseum and the local community.

In the authors' opinion, a working platform is required to address the concerns of various sectors and to improve collaboration among the various stakeholders in the Houtong Coal Mine Ecological Park, in a manner consistent with the structure of the ecomuseum of Santo Adriano [15] (p. 249). Although local people established the Association for the Sustainable Development in the Place of Houtong, it only served as a platform for informing residents and encouraging them to participate in local affairs. In the short term, the local authority could use this platform for empowering the community and to exchange information and encourage cooperation among local departments, with a focus on tourism, cultural, social, public heath, animal protection and economic development issues. A long-term goal is to establish a committee specifically for the Houtong Coal Mine Ecological Park that can consider different opinions and needs of various stakeholders and include them or their representatives in the decision-making circle. Finally, this ecomuseum should be a locally owned institution that satisfies the needs of local people rather than only serving tourists.

\subsection{Local Development in the Houtong Coal Mine Ecological Park}

The implementation of mechanisms for preserving coal mining heritage in situ and reusing properties to create educational and visitors' facilities resulted in the establishment of three galleries and three tourism centers and the preservation of the ruins of three mines, the coal dressing plant, the coal bridge, the mining building, the garage, the railroad station, the transportation system and the mining workers' facilities (Figure 2); it has also supported various community activities, as described in the preceding section. Over time, the number of tourists has gradually and continuously increased.

According to data that is published by Taiwan's central tourism authority, more than 1.9 million tourists visited Houtong Coal Mine Ecological Park in the years 2012-2014. The mean number of 
tourists to the park per month increased from 43,000 in 2012 to 49,000 in 2013 and to 67,000 in 2014. In 2014, the mean number of tourist visits per month was 1.36 times that in 2013. This increase is remarkable. To evaluate the effect of the ecomuseum on local development, the authors conducted a field investigation in the Houtong region at the end of 2013. At that time, the region had 37 shops, of which 23 (62\%) had been established after 2005, offering food (14), souvenirs (10), accommodations (four), educational services (four) and exhibitions (three). Twenty-four shops (65\%) were located in the Cat Village and the Station Area, offering food (15), souvenirs (nine), accommodation (two), educational services (two), exhibitions (two), bicycle rental (one) and groceries (one). These numbers reflect not only the positive effect of the ecomuseum project on the local economy, but also the problem of tourist agglomeration in the Cat Village and the Station Area.

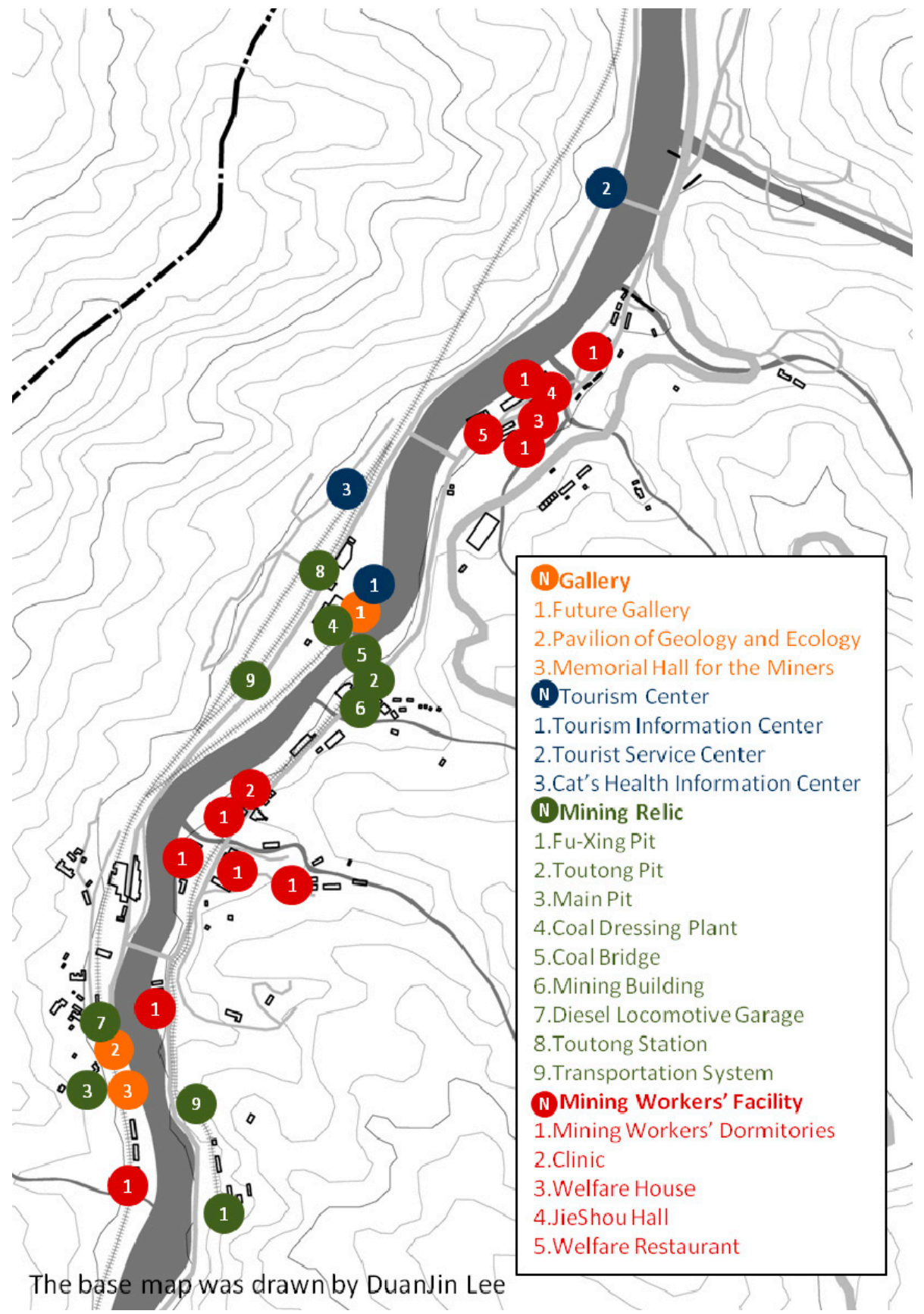

Figure 2. Map of facilities in Houtong Coal Mine Ecological Park. 
Along with the number of shops, ownership is another index of development. Of the 37 shops, only 11 had owners (30\%) from outside the area, while the others $(70 \%)$ were local residents. These "others" comprised 16 owners (43\%) who were permanent inhabitants and $10(27 \%)$ who had once left but returned for business or other reasons. According to relevant statistics, redevelopment in the Houtong region has helped maintained the quality of the place and has not been dominated by an excess of external investors. However, regardless of the amount of investment or commercial viability, the external owners tend to make more profit and be more professional in the managing of shops than the local owners, including those who left and returned, comparing with the permanent inhabitants, especially in the aspects of environment, service and products.

The Cat Village receives the highest density of tourists in the Houtong region. All nine shops in this small area opened after 2005. Five shops are temporary stalls; four shops are owned by permanent residents, and one is owned by an external investor. Half the owners of the other four shops are external investors, and the other half are local residents who had once left and have now returned to establish new shops. Accordingly, local residents, and especially permanent inhabitants-even those with the will to participate in the tourism industry - may only be able to earn a little money and must tolerate the noise, garbage and intrusion of tourists [33]. Simultaneously, tourists are unable to purchase the local services or products of high quality, so they have little incentive to spend money there. Therefore, despite the remarkable number of visitors, increasing prosperity through tourism has been difficult to maintain.

According to statistical data and previous studies, many tourists visited the Houtong Coal Mine Ecological Park during these past years, creating problems but also providing new opportunities for development. Street cats have attracted huge numbers of tourists to the Cat Village and the Station Area. However, since tourist information is limited, visitors simply lingered around the Cat Village and the Station Area and then explored other regions, such as the Pingxi region, where other significant coal mine heritage can be found. Tourists can also visit Yilan, Hualien and Taitung regions, which are popular tourist destinations in Taiwan. Without adequate information, however, most tourists only visit the Cat Village and use the facilities in front of the station for one or two hours before leaving for the other tourist destinations.

In 2013, local authorities proposed the establishment of a "Cat's Health Information Center" in Cat Village. The Association for the Sustainable Development in the Place of Houtong was invited to manage this new facility - not only to provide necessary information about animal welfare and protection, but also to direct visitors away from the Station Area to ease the pressure on one particular destination by encouraging them to properly experience the coal mining heritage. Community organizations or the local authority should also assist local residents, especially the permanent inhabitants of the Cat Village, to engage actively with the tourism industry. Owing to the tension between daily living and tourism, most shop owners can only set up temporary stalls in front of their homes. Improving product selection and providing stall decorations and relevant services may be a useful strategy. The opening of a shop on an empty or abandoned site by residents with the will to do it would be better in terms of management. Local authorities can empower residents to integrate the image of street cats with the coal mining heritage while reinventing tangible products or even intangible services associated with the locality. Residents may then benefit from tourists' visits and consolidate their new identity (based on the street cats) while strengthening their historic identity (based on coal mining). The gap between community 
empowerment and the tourism industry may thus be reduced or even eliminated by applying the concept of "tourism community empowerment", which interactively connects community empowerment with tourism, as done in Japan [34]. This approach can provide important insights in many discussions of the local development of the ecomuseum [3,13,15,16,19,21,35,36].

\subsection{In Situ Preservation in Houtong Coal Mine Ecological Park}

In situ preservation is a critical difference between ecomuseums and traditional museums [16], and is affected by community participation and local development. Integrating these three processes can support the sustainability of an ecomuseum.

Hugues de Varine defined "sustainability" as the personal and collective commitment to recognize the value of the common natural and cultural heritage of humankind. Without sustainability, all so-called development plans and programs would remain rootless and have short-term results; it signals a responsibility of not only governments or local authorities but also of each citizen and community [37] (p. 59). According to Cole [38], sustainable development is not an appropriate perspective from which to view mining heritage tourism because the mining industry in its original guise is associated with environmental despoliation, socially unacceptable working practices and with economic decline; arguably, mining heritage tourism is unsustainable. However, the development of mining heritage tourism should be considered because of its current reinvention in the tourism industry and its compatibility with sustainability objectives, as evident in the Blaenavon Industrial Landscape, the Big Pit Mining Museum, the Beamish Museum, etc. [39-41].

Like mining heritage tourism, mining heritage ecomuseums repurpose the properties that arise from an unsustainable industry to generate a new sustainable vision and prospects for regional redevelopment in the future. However, if the vision of in-situ preservation were not to meet the needs of the local community, sustainable development would just be a slogan and not be a practical reality. Accordingly, sustainable ecomuseums are few in China [42] (p. 6).

The concept and theory of the ecomuseum are now being localized for Taiwan. Like the Gold Museum [43] (pp. 32-34), the Houtong Coal Mine Ecological Park has the outward appearance of an ecomuseum because cultural and natural heritage are preserved in their original locations, but community participation was neglected - at least initially. Fortunately, the Houtong Coal Mine Ecological Park became a true ecomuseum because of the integration of community activities and the museum operation. Tourism development has eased regional decline and improved economic and social conditions.

The re-development of this post-industrial region has threatened the preservation of the mining heritage sites that are not controlled by the local authority. Presently, in the Houtong Coal Mine Ecological Park, only one monument and four historical buildings are designated or registered under the Cultural Heritage Preservation Act, and these are just a few of the mining properties in the Houtong region. In the absence of legal protection, some mining properties have been sold by owners for demolition and further development; some have been preserved but reused for commercial purposes without regulation.

Designating or registering all the important properties individually is impossible in Taiwan. Registering an entire mining region as a cultural landscape site is preferable. Many authors have noted the importance and value of the cultural landscape to an ecomuseum $[3,13,15,16,21,35,36]$ but few 
have regarded it as a factor that should provide a basis for regulation. According to the Cultural Heritage Preservation Act, the local authority must develop specific principles that govern the preservation and management of a cultural landscape following registration, and develop preservation and maintenance plans based on those principles. The previous plan for the Houtong Coal Mine Ecological Park divided it into zones with various degrees of control, based on the importance or purpose of the properties therein. Unique properties can be designated or registered as monuments or historical buildings with special concerns or requirements. Accordingly, mining heritage will be well protected, and also proper constraints on the re-use or even exploitation will be set by law.

\section{Discussion}

This study examines sustainable development in the Houtong Coal Mine Ecological Park, its current state, and the mechanism by the community responds to the establishment of ecomuseums. Community participation and in-situ preservation have made the redevelopment of this post-mining region a positive economic opportunity but have had a negative effect on quality of life and the mining heritage preservation. To solve these problems, three strategies-establishing a public-private platform for collaboration, initiating tourism community empowerment and defining "cultural landscape" in law_are proposed. These strategies can help the Houtong Coal Mine Ecological Park to contribute to sustainable regional development (Figure 3).

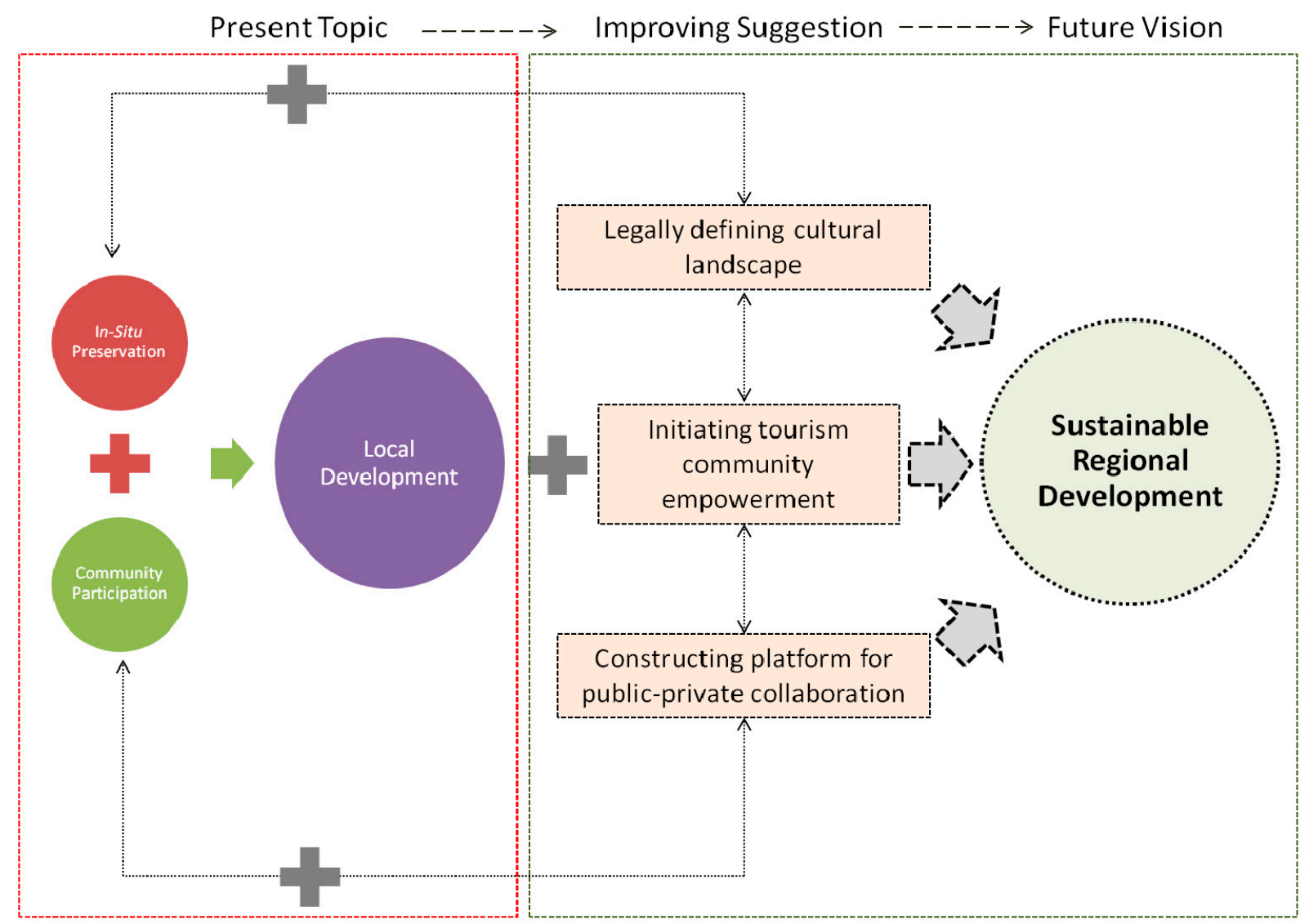

Figure 3. Sustainable development of the Houtong Coal Mine Ecological Park. 
As a representative ecomuseum of the second period of ecomuseums in Taiwan, the Houtong Coal Mine Ecological Park incorporates various improvements over the Gold Museum, especially with respect to the principle of "Encompassing a 'geographical' territory that can be determined by different shared characteristics" in the 21 Ecomuseum Principles [7] (pp. 92-93). However, the initial neglect of community participation, inadequate public-private partnership, and insufficient preparation for the local development in the following stage, all raised many problems, which had to be solved by the mechanism that is presented in Figure 3. Fortunately, in the 2010s, the Daxi Wood Art Ecomuseum and the Togo Art Museum established new paradigms for the establishment of ecomuseums by local authorities and community organizations, providing a basis for general ecomuseum development in Taiwan.

With respect to the Daxi Wood Art Ecomuseum, the local authority did as much as possible to publicize the master plan; to elicit local residents' opinions about this ecomuseum, and to encourage community participation in management (Figure 4). It initiated a "street corner museum" project to invite local shops to become partners and to establish private "satellite museums" to exhibit local properties. A stable and permanent public-private partnership was thus established.

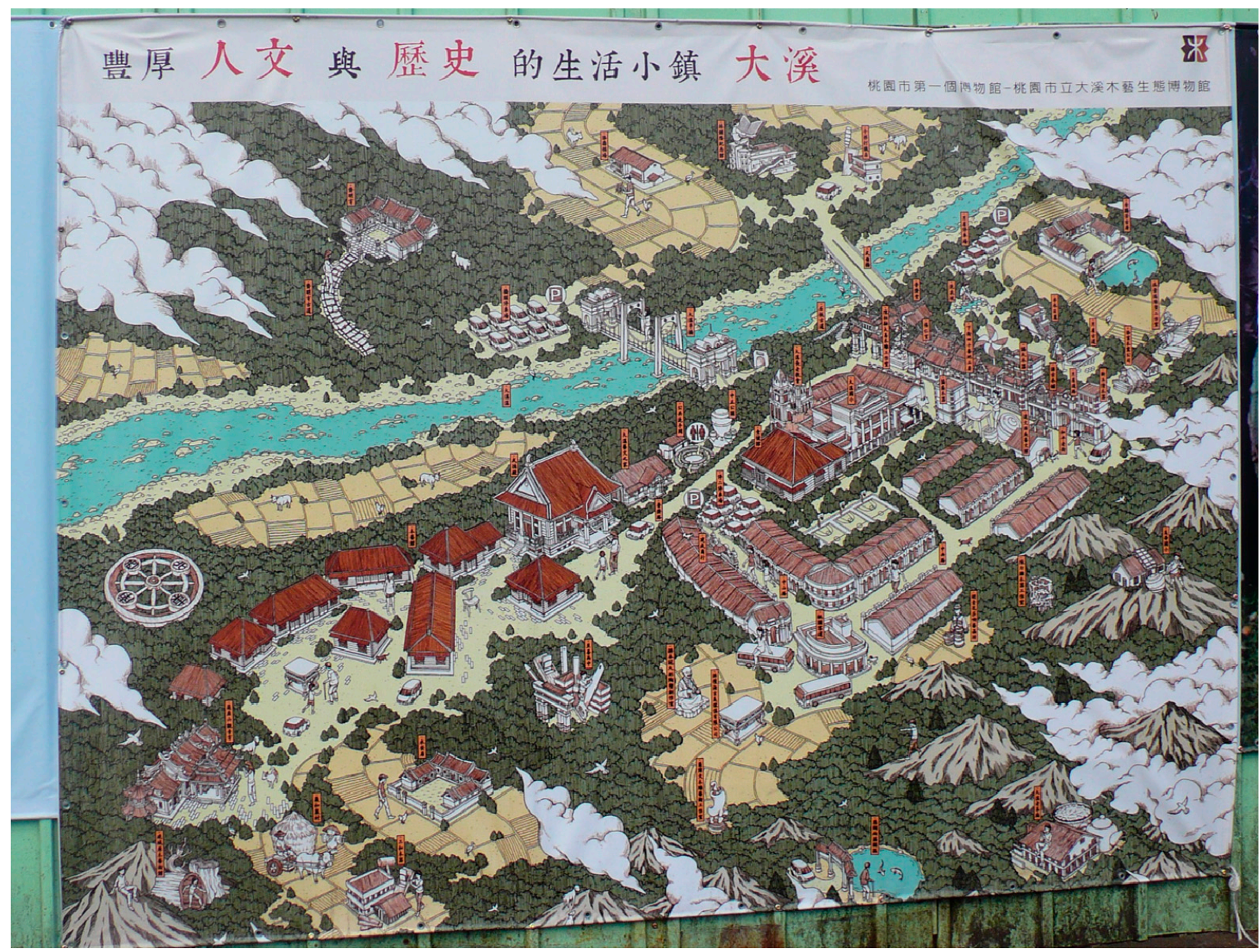

Figure 4. Future map of Daxi Wood Art Ecomuseum.

With respect to the Togo Art Museum, a local organization considered various developmental strategies for rural villages. This ecomuseum exhibits not only art and art installations in the village but also advocates: "the aesthetics of rural life as art", "the fruits of agriculture as art" and "the rural environment as an art museum". Since 2012, it has held modern art exhibitions in the houses of the 
villagers (Figure 5), some of which are being developed according to a long-term vision rather than temporary usage plan, encouraging more local people to participate in these projects. Accordingly, extensive external investments in most popular tourist destinations can be controlled.

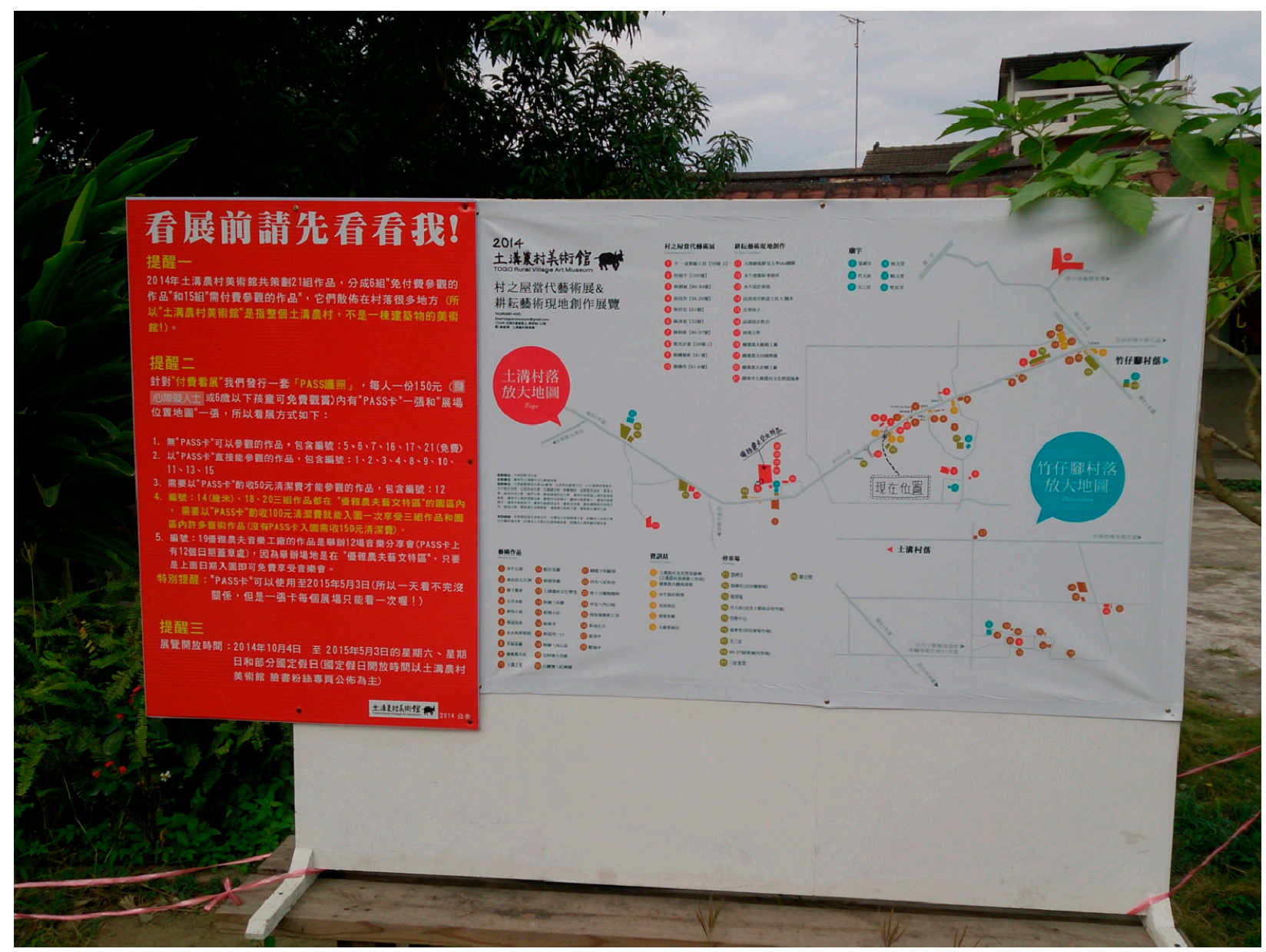

Figure 5. Map of 2014 modern art exhibition at Togo Art Museum.

Fully accepting Davis' idea that ecomuseums should be interconnected with the community and the environment [7], the authors have changed "museum" in the inner-most circle in Figure 6 to "ecomuseum". The three main aspects of ecomuseums that should be considered altogether are community participation, in-situ preservation, and local development, and are to the development of ecomuseums what the blades are to a turbine. Moreover, to develop principles and guidance for the establishment of an ecomuseum, Mayrand's "creativity triangle" with a three-year development cycle is used [7] (p. 86) [44,45], but with the three stages of pre-museology, museology, and post-museology. From our perspective, in practice, the development of an ecomuseum can be divided into three stages of "estimation", "preparation", and "operation". Within these three stages, six steps and 11 tasks are identified (Figure 6). In the first stage, beyond establishing the geographical region and context, actively collecting local residents' opinions is important. Local residents should have the right to express their opinions in the initial stage, including the opinion that the ecomuseum project should be rejected. In the second stage, before the infrastructure and facilities are constructed, an investigation should be conducted, and a plan for the management of the ecomuseum that involves the participation of local people should be established. In the third stage, the three strategies in Figure 3 are applied, emphasizing 
the mediation and integration of regional development issues. This overall process should take into account local conditions and provides a framework for recommendations for other ecomuseums in Taiwan that promote sustainable development.

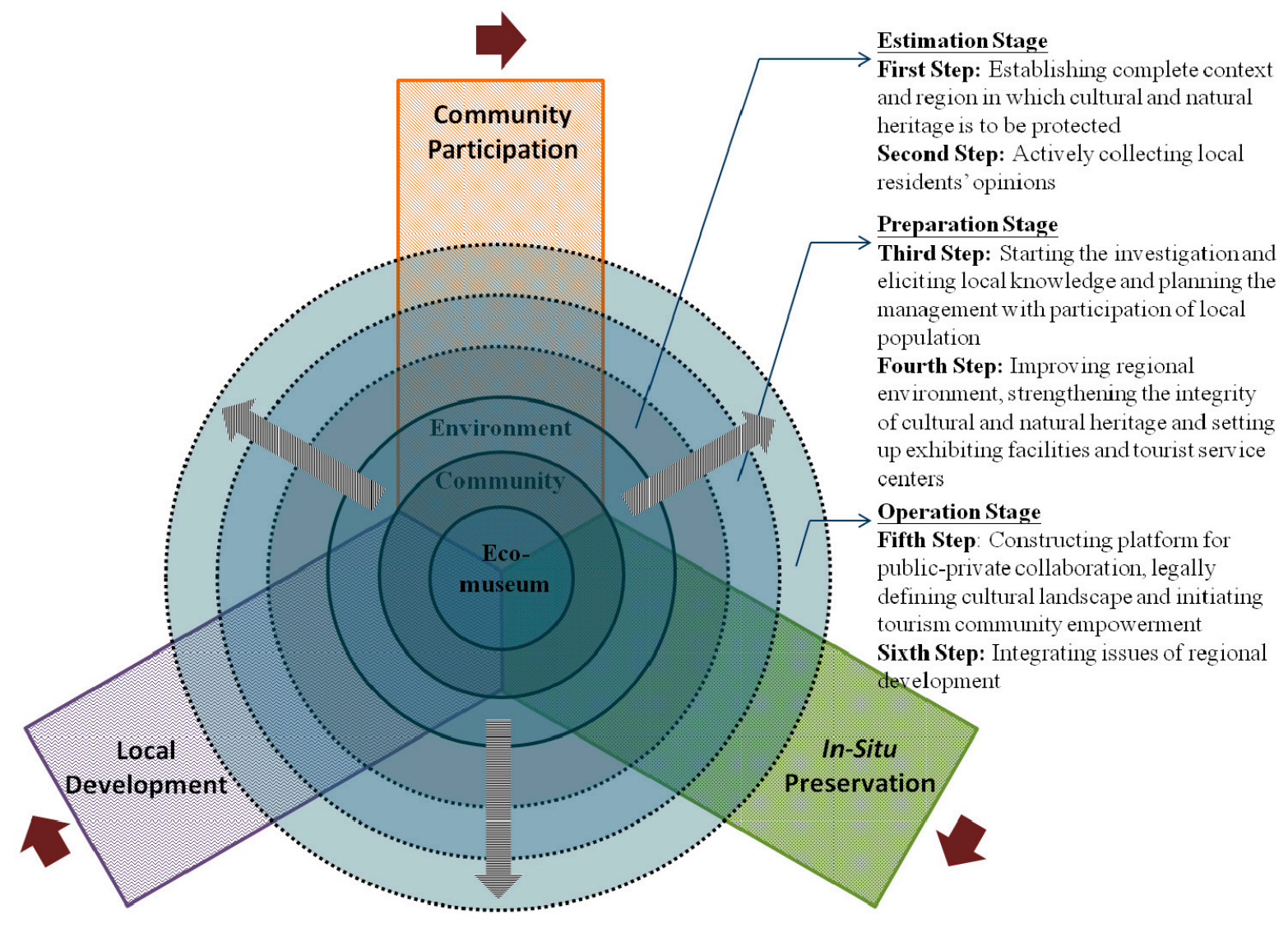

Figure 6. Proposed process of development of ecomuseums in Taiwan.

\section{Further Research}

Davis stated "ecomuseums require better strategic planning, both to guide the long-term development of organizations and to allow delegation of power from the founder group to a wider community" [7] (p. 94). Based on studies of the Houtong Coal Mine Ecological Park, this work proposes three strategies for solving the three main problems associated with ecomuseums (community participation, local development, in-situ preservation)—which are establishing a public-private collaborating platform, initiating tourism community empowerment, and legally defining the cultural landscape. However, in the initial stage of establishment of an ecomuseum, various steps must be implemented. Fortunately, in the 2010s, the Daxi Wood Art Ecomuseum and the Togo Art Museum were initiated, established and managed. The planning strategies and processes used motivated the proposal of an ecomuseum development mechanism for Taiwan (Figure 6).

Based on the four cases in this article, the Gold Museum, the Houtong Coal Mine Ecological Park, the Daxi Wood Art Ecomuseum and Togo Art Museum adopted two, four, eight and nine of the 11 tasks, respectively (Table 1). In the Estimation Stage and the Preparation Stage, the Daxi Wood Art Ecomuseum and the Togo Art Museum represented obvious improvements over the Gold Museum and the Houtong Coal Mine Ecological Park, especially with respect to community participation. In the 
Operation Stage, the Togo Art Museum and the Daxi Wood Art Ecomuseum provide better models for the construction of a public-private collaborating platform and the initiation of tourism community empowerment. Only legally protecting the cultural landscape and integrating regional development issues need more practical cases to elucidate the effectiveness and the actual process of developing ecomuseums in detail. Fortunately, as part of a project sponsored by the Bureau of Cultural Heritage, preliminary discussions about the Houtong coal mine cultural landscape issue began in 2014 and may lead to the first attempt to implement the ideas in this work. These attempts may validate the proposed mechanism in a local context.

Table 1. Evaluation of four ecomuseums using the proposed development mechanism of ecomuseums.

\begin{tabular}{|c|c|c|c|c|c|c|c|}
\hline Stage & Step & & Task & $\begin{array}{c}\text { Gold } \\
\text { Museum }\end{array}$ & $\begin{array}{c}\text { Houtong Coal Mine } \\
\text { Ecological Park }\end{array}$ & $\begin{array}{l}\text { Daxi Wood Art } \\
\text { Ecomuseum }\end{array}$ & $\begin{array}{l}\text { Togo Art } \\
\text { Museum }\end{array}$ \\
\hline \multirow[t]{2}{*}{ Estimation } & 1 & 1 & $\begin{array}{l}\text { Establishing complete context and region in which } \\
\text { cultural and natural heritage is to be protected }\end{array}$ & & $\bullet$ & $\bullet$ & $\bullet$ \\
\hline & 2 & 2 & Actively collecting local residents' opinions & & & $\bullet$ & $\bullet$ \\
\hline \multirow{4}{*}{ Preparation } & 3 & 3 & $\begin{array}{l}\text { Starting the investigation and eliciting } \\
\text { local knowledge } \\
\text { Planning the management with participation of } \\
\text { local population }\end{array}$ & $\bullet$ & $\bullet$ & $\bullet$ & $\begin{array}{l}\bullet \\
\bullet\end{array}$ \\
\hline & \multirow{3}{*}{4} & 5 & Improving regional environment & & $\bullet$ & $\bullet$ & $\bullet$ \\
\hline & & 6 & $\begin{array}{l}\text { Strengthening the integrity of cultural and } \\
\text { natural heritage }\end{array}$ & & & • & • \\
\hline & & 7 & $\begin{array}{l}\text { Setting up exhibiting facilities and tourist } \\
\text { service centers }\end{array}$ & $\bullet$ & $\bullet$ & $\bullet$ & • \\
\hline \multirow{4}{*}{ Operation } & \multirow{3}{*}{5} & 8 & $\begin{array}{l}\text { Constructing platform for public-private } \\
\text { collaboration }\end{array}$ & & & $\bullet$ & $\bullet$ \\
\hline & & 9 & Legally defining cultural landscape & & & & \\
\hline & & 10 & Initiating tourism community empowerment & & & & $\bullet$ \\
\hline & 6 & 11 & Integrating issues of regional development & & & & \\
\hline
\end{tabular}

With reference to the 21 Ecomuseum Principles and related research [7] (pp. 92-94), the core issues of ecomuseums are addressed comprehensively. The authors have examined state-of-the-art ecomuseums and proposed a development mechanism that is consistent with the specific socio-economic environment of Taiwan, and may be applicable outside Taiwan.

The Legislative Yuan of Taiwan approved the "Museum Act" on 15 June 2015. Hopefully, the government will ensure that ecomuseums are covered by this law to promote their development under the relevant regulations. Then, the ecomuseum development mechanism for Taiwan that is proposed in this study will be applicable to the development of new ecomuseums and the management of existing ones, allowing the proposed mechanism to be examined, tested and improved. Further studies are required to evaluate this new mechanism of development. 


\section{Acknowledgments}

The authors are grateful to anonymous reviewers for their constructive comments on the earlier version of this paper. We are also grateful to the editors and the editorial office for their kind assistance. Ted Knoy is appreciated for his editorial assistance.

\section{Author Contributions}

Zhen-Hui Liu carried out the action research, result analyses and drafted the manuscript, which was revised by Yung-Jaan Lee. All authors gave their approval of the version submitted for publication.

\section{Conflicts of Interest}

The authors declare no conflict of interest.

\section{References}

1. Chagas, M.; dos Santos, P.A.; Glas, T. Sociomuseology in Movement: MINOM Rio Declaration. Museum Int. 2014, doi:10.1111/muse. 12025.

2. Keyes, A.J. Local Participation in the Cowichan and Chemainus Valleys Ecomuseum: An Exploration of Individual Participatory Experience. Master's Thesis, The University of British Columbia, Vancouver, BC, Canada, 1992.

3. Chang, C. Community Involvement \& Ecomuseums: Towards a Mutual Approach to Ecomuseology and Landscape Studies. Ph.D. Thesis, Swedish University of Agricultural Sciences, Alnarp, Sweden, 2015.

4. Rivière, G.H. The Ecomuseum-An Evolutive Definition. Museum 1985, 148, 182-183.

5. Babić, D. Experiences and (hidden) Values of Ecomuseums. Ethnol. Res. 2009, 14, 237-252.

6. Ministère de la Culture et de la Communication. Instruction du 4 Mars 1981 du Ministre de la Culture et de la Communication; Ministère de la Culture et de la Communication: Paris, France, 1982. (In French)

7. Davis, P. Ecomuseums: A Sense of Place, 2nd ed.; A \& C Black: Edinburgh, UK, 2011.

8. Long Networks, Ecomuseums and Europe. Available online: http://www.mondilocali.it/wp-content/ uploads/2010/09/Declaration-of-Intent-2004.pdf (accessed on 24 September 2015).

9. JECOMS. JECOMS 2009 Ecomuseum Charter; JECOMS: Miyagawa, Japan, 2009. (In Japanese)

10. $\mathrm{Su}, \mathrm{D} . \mathrm{H}$. The Concept of the Ecomuseum and its Practice in China. Museum Int. 2008, doi:10.1111/j.1468-0033.2008.00634.x.

11. Su, D.H.; Zhang, J.P.; Davis, P.; de Varine, H.; Maggi, M. Communication and Exploration-Guiyang, China 2005, 1st ed.; Giunta della Provincia autonoma di Trento: Trento, Italy, 2005.

12. Cândido, M.M.D. Heritage and Empowerment of Local Development Players. Museum Int. 2014, doi:10.1111/muse.12014.

13. Terzić, A.; Bjeljac, Ž.; Jovičić, A.; Penjišević, I. Cultural Route and Ecomuseum Concepts as a Synergy of Nature, Heritage and Community Oriented Sustainable Development: Ecomuseum "Ibar Valley" in Serbia. Eur. J. Sustain. Dev. 2014, 3, 1-16. 
14. Kim, J.Y.; Lee, J.Y. Development of Local Cultural Resources Based on the Concept of Ecomuseum-Focusing on Cheorwon, Gangwon Province. IJMUE 2013, 8, 297-302.

15. González, P.A.; Fernández, J.F. Rural Development and Heritage Commons Management in Asturias (Spain): The Ecomuseum of Santo Adriano. JSSP 2013, 2, 245-253.

16. Sanya, T. Talking Heritage: Africa at the Crossroads of Tradition and Modernity. Afr. Sociol. Rev. 2013, 17, 2-23.

17. Ohara, K. Relationship between Peoples' Local Actions and Traditional Museums - Case Study on Miura Peninsula Ecomuseum as the Network to Integrate Local Resources in the Area. In Proceeding of Ecomuseums 2012 - 1st International Conference on Ecomuseums, Community Museums and Living Communities, Seixal, Portugal, 19-21 September 2012; Lira, S., Amoeda, R., Pinheiro, C., Davis, P., Stefano, M., Corsane, G., Eds.; Green Lines Institute for Sustainable Development: Barcelos, Portugal; pp. 257-266.

18. Nitzky, W. Mediating Heritage Preservation and Rural Development: Ecomuseum Development in China. Urban Anthrop. 2012, 41, 367-417.

19. Cerleux, A.L.; Peptenatu, D.; Merciu, C.; Drăghici, C.; Pintilii, R. Ecomuseums, a New Form of Revitalization of Spaces and their Role in Territorial Management Policies. Ann. Valahia Univ. Târgovişte Geogr. Ser. 2011, 11, 151-161.

20. Ohara, K. What Have We Learnt and Should We Learn from the Scandinavian Ecomuseums? A Study on Museological Way to Make Sustainable Community. J. Jpn. Ecomuseol. Soc. 2008, 13, 43-51.

21. Borrelli, N.; Davis, P. How Culture Shapes Nature: Reflections on Ecomuseum Practices. Nat. Cult. 2012, 7, 31-47.

22. Giménez-Cassina, E. Who am I? An Identity Crisis Identity in the New Museologies and the Role of the Museum Professional. Cad. Sociomuseol. 2010, 37, 25-41.

23. Engström, K. The Ecomuseum Concept is Taking Root in Sweden. Museum 1985, 148, 206-210.

24. Fuller, N.J. The Museum as a Vehicle for Community Empowerment: The Ak-Chin Indian Community Ecomuseum Project. In Museums and Communities: The Politics of Public Culture, 1st ed.; Karp, I., Kreamer, C.M., Levine, S., Eds; Smithsonian Institution: Washington, DC, USA, 1992; pp. 327-365.

25. Hubert, F. Ecomuseums in France: Contradictions and Distortions. Museum 1985, 148, 186-190.

26. Rivard, R. Ecomuseums in Quebec. Museum 1985, 148, 202-205.

27. Samson, D. The Training Needs of Québec Museums. Muse 1995, Winter, 51-53.

28. Hudson, K. The Dream and the Reality: Kenneth Hudson Discusses 20 Years of Ecomuseums and Ecomuseology. Museums J. 1992, 92, 27-31.

29. Chang, Y.T. Ecomuseums: The Rise of A Cultural Movement, 1st ed.; Five Senses Arts Management: Taipei, Taiwan, 2004. (In Chinese)

30. Lee, Y.J.; Wang, B.C.; Chen, P.C. Exploring Sustainable Development of Cultural Living Circles through Action Research: The Case of Sanyi Township, Miaoli, Taiwan. Syst. Pract. Act. Res. 2013, 26, 239-256.

31. Cosmos INC. Progressive Environmental INC. Houdong Memorial Park of Coal Mining. Taiwan Archit. Mag. 2009, 35, 68-74. (In Chinese)

32. Levin, M.; Martin, A.W. The Praxis of Educating Action Researchers: The Possibilities and Obstacles in Higher Education. Act. Res. 2007, 5, 219-229. 
33. Urry, J. The Tourist Gaze, 2nd ed.; Sage Publications: London, UK; Thousand Oaks, CA, USA; New Delhi, India, 2002.

34. Nishimura, Y. (Ed.) Kankou Machidukuri: Machi Ziman Kara Hajimaru Chiki Management; Gakugei Shuppansha: Kyoto, Japan, 2009. (In Japanese)

35. Badiali, F.; Piacente, S. The Study of the Landscape: From a Holistic Approach to a Social Concept of Knowledge. Ann. Geophys. 2012, 55, 481-485.

36. Corsane, G.; Davis, P.; Elliott, S.; Maggi, M.; Murtas, D.; Rogers, S. Ecomuseum Performance in Piemonte and Liguria, Italy: The Significance of Capital. Int. J. Herit. Stud. 2007, 13, 224-239.

37. De Varine, H. Ecomuseology and Sustainable Development. In Communication and Exploration-Guiyang, China 2005, 1st ed.; Su, D.H., Zhang, J.P., Davis, P., de Varine, H., Maggi, M., Eds; Giunta della Provincia Autonoma di Trento: Trento, Italy, 2005; pp. 59-62.

38. Cole, D. Exploring the Sustainability of Mining Heritage Tourism. J. Sustain. Tour. 2004, 12, 480-494.

39. Walker, D. Towards a Beneficial World Heritage: Community Involvement in the Blaenavon Industrial Landscape. Museum Int. 2011, doi:10.1111/j.1468-0033.2012.01760.x.

40. Pitchford, S. R. Ethnic Tourism and Nationalism in Wales. Ann. Tour. Res. 1995, 22, 35-52.

41. Power, R. "After the Black Gold": A View of Mining Heritage from Coalfield Areas in Britain. Folklore 2008, 119, 160-181.

42. Su, D.H. The Establishment and Sustainable Development of Ecomuseums in China. In Communication and Exploration—Guiyang, China 2005, 1st ed.; Su, D.H., Zhang, J.P., Davis, P., de Varine, H., Maggi, M., Eds.; Giunta della Provincia Autonoma di Trento: Trento, Italy, 2005; pp. 5-6.

43. Chang, Y.T. Taiwan's Ecomuseums: The Past and the Present. In Communication and Exploration-Guiyang, China 2005, 1st ed.; Su, D.H., Zhang, J.P., Davis, P., de Varine, H., Maggi, M., Eds.; Giunta della Provincia Autonoma di Trento: Trento, Italy, 2005; pp. 27-36.

44. Mayrand, P. La Réconciliation Possible de deux Languages. Les Cah. Dév. Local 1994, 3, 3-5. (In French)

45. Mayrand, P. L'exposition à L'heure Juste du Développement Local: Cycle Théoretique de Trois ans. Master's Thesis, Reinwardt Academy, Amsterdam University of the Arts, Amsterdam, The Netherlands, 1998. (In French)

(C) 2015 by the authors; licensee MDPI, Basel, Switzerland. This article is an open access article distributed under the terms and conditions of the Creative Commons Attribution license (http://creativecommons.org/licenses/by/4.0/). 